\title{
Hubungan Motivasi dan Beban Kerja Terhadap Kinerja Bidan Desa Dalam Pelayanan Pos Kesehatan Desa (Poskesdes) Di Wilayah Kerja Puskesmas Boja Kendal
}

\author{
Widya Mariyana $^{1 *}$, Kusyogo $^{2 *}$ \\ 1 Sekolah Tinggi Ilmu Kesehatan Telogorejo, Semarang, Jawa Tengah, Indonesia \\ 2 Universitas Diponegoro, Semarang, Jawa Tengah, Indonesia \\ *widya_mariyana@stikestelogorejo.ac.id, kusyogo_cahyo80@gmail.com
}

\section{ARTICLE INFO}

\section{Article history:}

Received November 07,2021

Accepted December 02, 2021

Published December 06, 2021

\section{Kata Kunci:}

Motivasi

Kinerja bidan

Beban Kerja

Key words:

Motivation

Midwife Performance

Workload

\section{DOI:}

https://10.48092/jik.v8i1.136

\section{ABSTRAK}

Latar Belakang: Target pencapaian PWS-KIA yang belum mencapai target, masih ditemukannya kasus gizi kurang, lemahnya pelayanan yang diberikan oleh bidan desa, hasil supervisi oleh Puskesmas ke lapangan terlihat sarana dan prasarana Poskesdes yang masih kurang, supervisi pada bidan desa sudah berjalan tetapi belum optimal. Tujuan penelitian ini adalah untuk mengetahui hubungan motivasi dan beban kerja terhadap kinerja bidan desa dalam pelayanan Poskesdes di Wilayah Kerja Puskesmas Boja Kendal. Metode: Desain penelitian observasional dengan pendekatan cross sectional. Populasi adalah 20 bidan desa di wilayah kerja Puskesmas Boja Kendal, teknik sampel menggunakan total sampling. Instrumen yang digunakan dalam penelitian ini adalah kuesioner. Analisa data menggunakan uji chi-square. Hasil: Motivasi bidan desa mayoritas kategori baik 12 responden $(88,2 \%)$. Beban kerja bidan desa mayoritas kategori baik 17 responden $(85 \%)$. Kinerja bidan desa dalam pelayanan pos kesehatan desa mayoritas kategori baik 12 responden $(59,2 \%)$. Hasil uji chi-square $p=0.003$ ada hubungan beban kerja dengan kinerja, $\mathrm{p}=0.001$ ada hubungan motivasi kinerja. Kesimpulan: Dapat disimpulkan bahwa motivasi dan beban kerja berhubungan dengan kinerja bidan desa dalam pelayanan poskesdes.

\section{ABSTRACT}

The Relationship between Motivation and Workload on the Performance of Village Midwives in Village Health Post Services (Poskesdes) in the Work Area of the Boja Kendal Health Center

Background: The PWS-KIA achievement target has not yet reached the target, cases of malnutrition are still found, the service provided by village midwives is weak, the results of supervision by the Puskesmas to the field show that Poskesdes facilities and infrastructure are still lacking, supervision of village midwives has been running but not optimal. The purpose of this study was to determine the relationship between motivation and workload on the performance of village midwives in Poskesdes services in the Boja Kendal Health Center Work Area. Methods: research design Observational with aapproach cross sectional. The population is 20 village midwives in the working area of the Boja Kendal Health Center, the sample technique uses total sampling. The instrument used in this study was a questionnaire. Data analysis usingtest chi-square. Results: The motivation of the village midwives was the majority in the good category, 12 respondents $(88.2 \%)$. The majority of village midwives workload in good category 17 respondents (85\%). The performance of village midwives in village health post services was in the good category of the majority of 12 respondents (59.2\%). The results of the chi-square test $p=$ 0.003 there is a relationship between workload and performance, $p=0.001$ there is a relationship between motivation and performance. Conclusion: It can be concluded that motivation and workload are related to the performance of village midwives in poskesdes services.

Thisopenaccessarticleisunderthe CC-BY-SAlicense. 


\section{PENDAHULUAN}

Keberhasilan Desa siaga sebagai wujud upaya kesehatan berbasis masyarakat, dimulai dengan keberadaan sebuah Pos Kesehatan Desa (Poskesdes), yang pemanfaatannya sangat tergantung kepada ketepatan penerapan langkah-langkah dalam pendekatan edukatif dan pengorganisasian masyarakat yang dimulai dari tingkat desa, Puskesmas, Rumah Sakit dan Dinas Kesehatan Kabupaten (Cahyo, 2010). Dalam keberhasilannya perlu diadakan revitalisasi baik dalam sumber daya manusia, prasarana-sarana, maupun pendanaannya serta didukung oleh supervisi dari pihak yang bertanggung jawab (Depkes RI, 2016).

Bidan di desa dalam melaksanakan pedoman pelayanan kesehatan di Poskesdes yaitu tindakan pelayanan yang memenuhi syarat yang harus diterapkan dalam pelayanan yang diberikan pada pasien dan masyarakat. Pelayanan yang diberikan adalah pelayanan kesehatan dasar, pelayanan kesehatan ibu dan anak, pelayanan $\mathrm{KB}$, konseling, pelayanan kesehatan dengan kasus tertentu, pelayanan laboratorium dasar, dan pelayanan kefarmasian (Emi Y, 2012). Maka untuk penyelenggaraan pelayanan Poskedes harus tersedia standar prosedur pelayanan, perlengkapan dan peralatan kesehatan minimal, adanya bangunan fisik yang mendukung serta adanya hasil musyawarah masyarakat desa yang telah disepakati. (Depkes RI, 2016)

Secara garis besar Poskesdes yang ada setelah dilakukan supervise oleh puskesmas dan Dinaks Kesehatan kabupaten Kendal dari 20 bidan desa terdapat 16 responden $(61,7 \%)$ yang sudah sudah terlatih dan mempunyai bangunan poskesdes. Pedoman Poskesdes sudah dilaksanakan, mempunyai SK kepala desa, memberikan pelayanan poskesdes sesuai pedoman sebanyak 18 bidan (87,97\%) (Dinkes Kab Kendal, 2015). Data tersebut menunjukkan belum semua poskesdes dapat melaksanakan pedoman pelayanan poskesdes. Kenyataan dilapangan banyak sekali hambatan dan variasi dalam penerapan poskesdes, masih rendahnya partisipasi masyarakat sehingga mempengaruhi motivasi bidan desa dalam memberikan pelayanan poskesdes, disamping itu pengelolaan dana, sarana dan prasarana, serta pengelolaan management poskesdes yang belum optimal, sehingga perlu improvisasi dan modifikasi yang dapat disesuaikan dengan kondisi dan permasalahan setempat, contohnya peningkatan kegaitan posyandu secara rutin, pemanfaatan poskesdes di gunakan untuk pertolongan persalinan, musyawarah masyarakat desa (MMD)/ rembuk desa, adanya forim rebuk desa/FKD secara rutin (Profil Kesehatan Jateng, 2017). Dengan cara mengembangkan poskesdes menjadi desa siaga yaitu masyarakat sudah menyadari bahwa poskesdes adalah milik masyarakat sehingga semua kegaiatan poskesdes didukung sepenuhnya oleh masyarakat (Depkes RI, 2016).

\section{METODE}

Jenis Penelitian adalah kuantitatif dengan pendekatan cross sectional. Variabel bebas terdiri dari motivasi dan beban kerja dan variabel terikat kinerja bidan desa dalam pelayanan poskesdes. Sehingga populasi adalah seluruh bidan yang memberikan pelayanan poskesdes sebanyak 20 bidan. Metode pengambilan sampel dalam penelitian ini adalah total sampling.

Analisa data dilakukan secara univariat dan bivariat dengan menggunakan Distribusi Frekuensi dan uji Chi Square. Pengukuran variabel motivasi skor untuk pernyataan positif (favorable) yaitu sangat setuju: 4, setuju: 3, tidak setuju:2, sangat tidak setuju: 1, untuk pernyataan negative (unfavorable): sangat setuju :1, setuju:2, tidak setuju:3, sangat tidak setuju: 4. Untuk pernyataan kinerja skor penyataan positif (favorable): tidak dilakukan:1 dan dilakukan :2 sedangkan untuk skor pernyataan negative (unfavorable) tidak dilakukan:2 sedangkan untuk skor pernyatan negatif (unfavorable): tidak dilakukan:2 dan dilakukan:1. 


\section{HASIL DAN PEMBAHASAN}

\section{Karakteristik Responden}

Tabel 1.Distribusi Frekuensi Karakteristik Responden

\begin{tabular}{lcc}
\hline Karakteristik & Frekuensi & Persen (\%) \\
\hline Usia & & \\
26-35tahun & 12 & 72,4 \\
36-45tahun & 6 & 25,0 \\
46-55tahun & 2 & 2,6 \\
\hline Pendidikan & & \\
DIII & 18 & 94,7 \\
DIV & 2 & 5,3 \\
\hline Masa Kerja & & \\
$<5$ tahun & 8 & 9,2 \\
$>5$ tahun & 12 & 90,8 \\
\hline
\end{tabular}

Berdasarkan tabel 1 frekuensi di atas di ketahui usia responden mayoritas antara 26-35 tahun sebesar $72,4 \%$ dengan tingkat Pendidikan di dominasi DIII sebesar 94,7\% dan masa kerja mayoritas lebih dari 5 tahun $90,8 \%$.

\section{Distribusi Responden Berdasarkan Variabel}

Tabel 2. Distribusi Frekuensi Responden berdasarkan Variabel Penelitian

\begin{tabular}{clcc}
\hline $\begin{array}{c}\text { Variabel } \\
\text { Penelitian }\end{array}$ & \multicolumn{1}{c}{ Kategori } & $\mathrm{n}$ & $\%$ \\
\hline Beban Kerja & Baik & 17 & 85 \\
& Kurang & 3 & 15 \\
\hline Motivasi & Baik & 12 & 88,2 \\
& Kurang & 8 & 11,8 \\
\hline Kinerja & Baik & 12 & 59,2 \\
& Kurang & 8 & 40,8 \\
\hline
\end{tabular}

Berdasarkan tabel 2 diatas menunjukan presentase responden dengan kategori baik pada beban kerja, motivasi dan kinerja bidan masingmasing sebesar $85 \%, 88,2 \%$ dan $59,2 \%$, sedangkan presentase responden dengan kategori kurang pada beban kerja, motivasi dan kinerja masing-masing sebesar $15 \%, 11,8 \%, 40,8 \%$.

Pada variabel motivasi, sebagian besar motivasi bidan desa adalah baik (88,2\%), akan tetapi masih ada motivasi bidan desa yang kurang yaitu pada pernyataan "saya merasa puas bila menyelesaikan tugas tepat waktu", sebesar $(5,3 \%)$, "saya tertantang untuk bekerja semaksimal mungkin dalam melaksanakan tugas sebagai pengelola poskesdes", sebesar $(5,3 \%)$ dan pernyataan "masyarakat merupakan patner kerja saya diposkesdes sehingga saya nyaman menjadi bidan di desa", sebesar $(5,3 \%)$.

Kategori kinerja dapat diketahui bahwa 3 pernyataan yang banyak di jawab "ya" oleh responden adalah pernyataan tentang "bidan pengelola KIA Puskesmas jarang melakukan supervisi pada bidan di desa pelaksana Poskesdes”, sebesar $(80,3 \%)$, pada pernyataan "Bidan pengelola KIA Puskesmas memberikan bantuan cara yang tepat dalam menyelesaikan masalah Poskesdes dengan baik", sebesar (73,7), dan pernyataan "Bidan pengelola KIA Puskesmas melakukan supervisi pada bidan di desa pelaksana Poskesdes”, sebesar $(69,7)$.

Berdasarkan hasil uji hipotesisi hubungan antara beban kerja dan kinerja menggunakan Chisquare dengan continuity correction $=0.003$ $(\mathrm{p}<0,05)$ berarti Ho ditolak dan Ha diterima, yang dapat disimpulkan bahwa ada hubungan antara beban kerja dengan kinerja bidan desa dalam pelayanan poskesdes.

Hasil pengujian hipotesis hubungan antara variabel motivasi dengan kinerja menggunakan uji Chi-Square dengan continuity correction $=0,001$ $(\mathrm{p}<0,05)$, berarti Ho ditolak dan Ha diterima yang dapat disimpulkan bahwa ada hubungan antara motivasi dengan kinerja bidan desa dalam pelayanan poskesdes.

Motivasi bidan desa dalam penelitian ini mayoritas dalam kategori baik, motivasi merupakan cerminan dari keinginan atau kemauan yang berasal dari diri untuk melakukan suatu aktivitas atau tindakan. Semakin tinggi motivasi tersebut, maka 
kecenderungan untuk bertindak akan semakin besar (Zameer, 2014).

Bidan yang memiliki motivasi baik akan membuat dirinya semangat dan berusaha keras untuk mencapai hasil kerja yang terbaik. Motivasi dalam penelitian ini lebih cenderung ke arah untuk mendapatkan prestasi dan penghargaan dari Puskesmas, sehingga motivasi bidan akan mempengaruhi kinerja cakupan persalinan bidan untuk menjadi lebih baik. Motivasi secara signifikan dapat mempengaruhi kinerja (Linda, 2011).

Kita dapat mengatakan bahwa jika manajemen puncak menempatkan fokus mereka pada motivasi maka akan tercapainya peningkatan positif dalam kinerja (Rautzul, 2016). Oleh sebab itu, Puskesmas harus menitikberatkan pada membuat kebijakan dalam hal pemberian reward kepada petugas Bidan yang mampu menunjukkan prestasi kinerja yang terbaik sehingga hal ini akan mampu memotivasi setiap bidan untuk dapat bekerja lebih baik lagi (Ita R, 2014).

Penelitian lain juga menemukan bahwa diantara faktor yang mempengaruhi peran bidan dalam pelaksanaan pelayanan kesehatan adalah motivasi yang kurang karena beban kerja yang berat serta waktu yang terbatas (Zameer, 2014). Intensitas kerja yang tinggi menjadikan bidan hanya memiliki waktu luang yang sedikit dan hal ini mengindikasikan adanya beban kerja mental.

\section{KESIMPULAN DAN REKOMENDASI}

Berdasarkan hasil penelitian dapat diketahui bahwa responden 20 bidan desa, dengan menggunakan total sampling. Jenis penelitian ini adalah kuantitatif dengan metode coss-sectional.Variabel yang berhubungan dengan kinerja adalah beban kerja dengan nilai $(\mathrm{p}=0,003)$, dan motivasi $(\mathrm{p}=0,001)$. Berdasarkan hasil uji hipotesisi hubungan antara beban kerja dan kinerja dilakukan dengan menggunakan Chi-square dengan continuity correction $=0.003(\mathrm{p}<0,05)$ berarti Ho ditolak dan Ha diterima yang dapat disimpulkan bahwa ada hubungan antara beban kerja dengan kinerja bidan desa dalam pelayanan poskesdes.

Berdasarkan hasil pengujian hipotesis hubungan antara variabel motivasi dengan kinerja dilaukan menggunakan uji Chi-Square dengan continuity correction $=0,001$ $(\mathrm{p}<0,05)$, berarti Ho ditolak dan Ha diterima yang dapat disimpulkan bahwa ada hubungan antara motivasi dengan kinerja bidan desa dalam pelayanan poskesdes.

\section{REFERENSI}

Cahyo IS.dkk. Posyandu Dan Desa Siaga. Jakarta: Muha Medika 2010

Depkes RI. Pedoman Pengembangan Desa Siaga Jakarta: 2016.

Dinkes Kabupaten Kendal. Rencana Strategis. Kendal: 2015

Emy Yulianti. (2012). Faktor-faktor Yang Mempengaruhi Kinerja Bidan Puskesmas Dalam Penanganan Ibu Hamil Risiko Tinggi di Kabupaten Pontianak. https://media.neliti.com/media/publications/9198 $1-$ ID

Ita Rahman (2014). Factor-faktor yang mempengaruhi kinerja bidan desa pada kunjungan neonatus. https://doi.org/10.5281/j\%20ners\%20community .v5i1.71

Linda Melianti. (2011). Faktor-faktor Yang Mempengaruhi Kinerja Bidan Di Desa Dalam Kegiatan Deteksi Dini Resiko Tinggi Ibu Hamil Di Wilayah Kerja Dinas Kesehatan Kabupaten Lombok Timur. https://poltekkesmataram.ac.id/wp-content/uploads/2015/08/7.982-993-Linda-Melianti.pdf

Notoatmodjo,S. Metodologi Penelitian Kesehatan. Jakarta: Rineka Cipta; 2012

Profil Kesehatan Provinsi Jawa Tengah. (2018) http://www.depkes.go.id/resources/download/pr ofil/PROFIL_KES_PROVIN SI_2017/13_Jateng_2017.pdf. Diakses pada tanggal 01 Januari 2019

Rahma Kusuma PW.(2016). Analisis faktor Yang Mempengaruhi Kinerja Bidan Dalam Pelayanan Antenatal Care di Puskesmas Kagook Kota Semarang. http://ejournal- 
Rauztul Jannah.(2016). Faktor-faktor Yang berhubungan Dengan Kinerja Bidan Dalam Pelayanan Ibu Hamil Di Wilayah Puskesmas Kuta Baro Aceh Besar. https://karil.uui.ac.id/berkas/121010300038-1

Saryono, \& Setiawan. (2011) .Metodologi dan aplikasi. Yogyakarta: Mitra Cendikia Press

Sugiono,Statistik untuk Penelitian:Afabeta;2012

Zameer, H., Ali, S., Nisar, W., \& Amir, M. 2014. The Impact Of The Motivation On The Employees Performance In Beverage Industry Of Pakistan. International Journal Of Academic Research In Accounting, Finance And Management Sciences, Vol. 4, No.1, January, 293-298 